\title{
CHANGES IN PLASMA CHOLINESTERASE ISOENZYMES DUE TO ORAL CONTRACEPTIVES
}

\author{
MARY WHITTAKER, A. R. CHARLIER AND S. RAMASWAMY \\ Chemistry Department, The University, Exeter, and \\ Family Planning Association
}

(Received 12th December 1970; revised 3rd May 1971)

Many changes have been noted in the plasma proteins of women taking oral contraceptives and a similarity between the metabolic effects of oral contraceptive therapy and pregnancy has been observed by Tyler (1964) as well as by Crawford \& Rudofsky (1966). The existence of diminished serum cholinesterase activity in pregnancy (Schnider, 1965; Robertson, 1966) and in women taking oral contraceptives (Robertson, 1967) is reported. Robertson (1967) has shown electrophoretic changes in serum plasma proteins during oral contraceptive therapy. In the present study, changes are reported in plasma cholinesterase isoenzymes in women taking oral contraceptives all of which contained oestrogen.

Thirty-eight plasma samples from healthy young women were examined by electrophoresis in $13.5 \%$ starch gel (Smithies, 1955) using 0.03 M-borate buffer

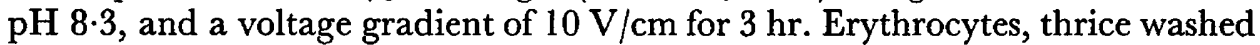
with isotonic saline, were disrupted by an ultrasonic disintegrator (MSE type E 7680/3) for about $30 \mathrm{sec}$ in order to free the acetylcholinesterase from the red cell stroma. These sonicates were examined in the above system. After electrophoresis, the gels were stained using $\alpha$-naphthyl acetate as substrate and the liberated $\alpha$-naphthol coupled with Fast-Red TR salt. The samples were supplied blind, a certain number of controls (pre-pill patients and patients using an intrauterine device) being included with samples from women taking oral contraceptives. Except for some ambiguity in six cases, it was readily apparent whether or not the sample was a control. Plate 1, Figure 1 illustrates the typical changes which appear to be confined to the faster moving and minor components of the isoenzyme pattern, the two major bands $\left(\mathrm{C}_{4}\right.$ and $\left.\mathrm{C}_{5}\right)$ being unaffected in intensity. No differences were detected in the effects of different oestrogen/ progestagen combinations. Only the activities of the isoenzymes appear to be affected, no changes in their mobilities were observed. Components $\mathrm{C}_{1}, \mathrm{C}_{2}$ and $\mathrm{C}_{3}$ were affected, with $\mathrm{C}_{3}$ being the most sensitive. The $\mathrm{C}_{5+}$ (in this zymogram, $\mathrm{C}_{6+}$ ) variant which is known to be associated with high plasma cholinesterase activity, was not observed (Harris, Hopkinson, Robson \& Whittaker, 1963). No changes were observed in erythrocyte esterase patterns as can be seen in P1. 1, Fig. 2. The observed changes appear to manifest themselves with some rapidity. One of the samples, taken 14 days after initiation of oral contraceptive treatment, was unequivocally positive, while another was correspondingly negative 21 days after discontinuing a 3-year course. A previous sample (which initiated this investigation but was not included in the present 
study) was observed to return to normal within 3 days of discontinuing treatment.

The existence of a pregnancy protein zone in serum was first described by Smithies (1959) and this was investigated by Cooper (1963) and Alfonso \& de Alvarez (1964), who also mentioned that the zone appears in the sera of women taking Enovid (G. D. Searle and Company, Chicago, Illinois). Margolis \& Kenrick (1969) established that this 'pregnancy protein' in serum was in fact oestrogen-dependent. The present study indicates that the 'pregnancy protein' is not a cholinesterase.

Previous workers have found that it is difficult to assess valid reasons for the decrease in plasma cholinesterase activity observed during pregnancy and oral contraceptive therapy. Pritchard (1955) suggested that the changes were primarily due to haemodilution. This explanation has been contraindicated by many workers and, for example, Wetstone, Lamotta, Middlebrook, Tennant \& White (1958) recorded that in spite of the expansion of plasma volume, the haematocrits did not change significantly. It would be reasonable to expect a decrease in intensity of all the isoenzyme bands of plasma cholinesterase if haemodilution is the cause of the low enzymatic activity but we have observed no changes in the major electrophoretic components, $\mathrm{C}_{4}$ and $\mathrm{C}_{5}$. The existence of differential alterations in the electrophoretic components of plasma cholinesterase in human pregnancy will be investigated.

The liver has been shown to be a target organ for the action of oestrogens (Song, Rifkind, Gilette \& Kappas, 1969) and altered plasma levels of enzymes synthesized in the liver in response to oestrogen administration have been reported (Seal \& Doe, 1969). Plasma cholinesterase is synthesized in the liver and yet only the minor electrophoretic components of this enzyme are affected by oral contraceptive therapy. The observed changes are readily reversible so that hepatic insufficiency is not an adequate explanation for the changes described.

The muscle relaxant, succinyl choline, is metabolized by plasma cholinesterase and Henriquet (1962) has suggested that the greater sensitivity to succinyl choline of patients at the end of pregnancy is due to low cholinesterase activity. Unfortunately, no attempt was made to exclude any of the serum cholinesterase variants which are known to be sensitive to this muscle relaxant (e.g. Whittaker, 1970). One of us (M.W.), in association with Dr M. D. Vickers, has investigated a few of these patients having an apnoea after the end of a Caesarean section during which succinyl choline had been given. Most of the individuals had an inherited atypical enzyme and the remainder were assumed to have developed an end-plate resistance ('dual block'). The present study indicated that women on contraceptives would not be expected to be sensitive to succinyl choline provided that the inherited atypical enzymes are absent or that an end plate resistance does not develop.

The possibility that there may be an interaction between circulating hormone and the enzyme is to be investigated. It is, however, reassuring that the reported changes appear to be readily reversible.

One of us (A.R.C.) would like to acknowledge a research studentship from the Medical Research Council. 

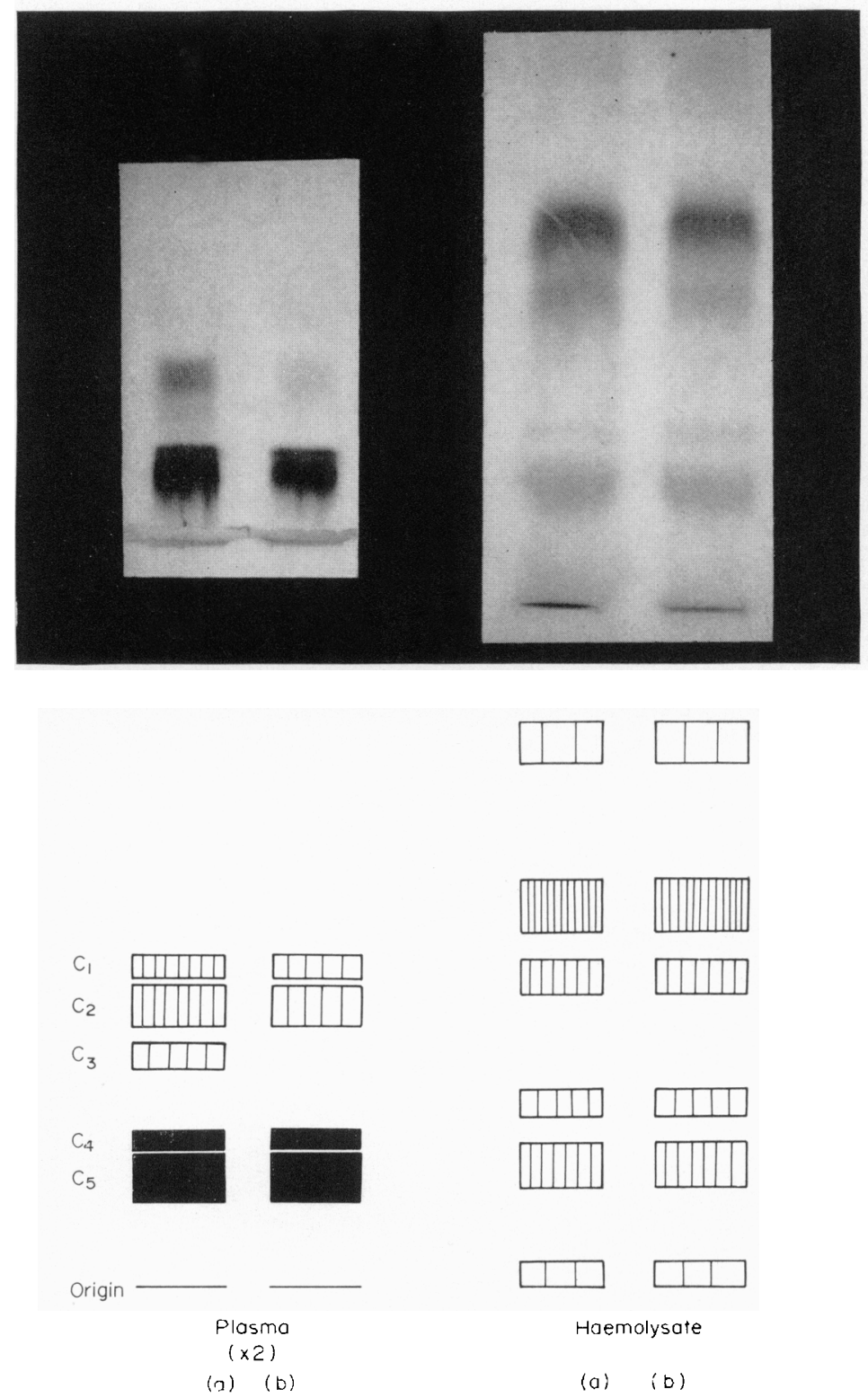

Esterase zymograms obtained from (a) controls and (b) patients taking oral contraceptives. 


\section{REFERENCES}

Alfonso, J. F. \& de Alvarez, R. R. (1964) New electrophoretic protein zone in pregnancy. Am. $\mathcal{F}$. Obstet. Gynec. 89, 204.

Cooper, D. W. (1963) A serum protein present in pregnant women. Nature, Lond. 200, 892.

CRAwFord, J. S. \& Rudofsky, S. (1966) Some alterations in the pattern of drug metabolism associated with pregnancy, oral contraceptives, and the newly born. Br. F. Anaesth. 38, 446.

Harris, H., Hopkinson, D. A., Robson, E. B. \& Whittaker, M. (1963) Genetical studies on a new variant of serum cholinesterase detected by electrophoresis. Ann. hum. Genet. 26, 359.

Henriquet, F. (1962) Relation between cholinesterase and succinyl choline in anaesthesia. Minerva anest. $28,393$.

Margolis, J. \& KenRICK, K. G. (1969) 'Pregnancy protein' in polyacrylamide gradient gel electrophoresis. Aust. F. exp. Biol. med. Sci. 47, 637.

Pritchard, J. A. (1955) Plasma cholinesterase activity in normal pregnancy and in eclamptogenic toxemias. Am. 7. Obstet. Gynec. 70, 1083.

Robertson, G. S. (1966) Serum cholinesterase deficiency. II. Pregnancy. Br. F. Anaesth. 38, 361.

Robertson, G. S. (1967) Serum protein and cholinesterase changes associated with contraceptive pills. Lancet, $\mathbf{i}, 67$.

SCHNiDER, S. M. (1965) Serum cholinesterase activity during pregnancy, labor and the puerperium. Anesthesiology, 26, 335.

SEAL, U. S. \& DoE, R. P. (1969) Effects of gonadal and contraceptive hormone in protein and amino acid metabolism. In: Metabolic Effects of Gonadal Hormones and Gontraceptive Steroids, p. 277. Eds. H. A. Salhanich, D. M. Kipnis, and R. L. Vande Wiele. Plenum Press, New York.

SMrTHIES, O. (1955) Zone electrophoresis in starch gels; group variations in the serum proteins of normal human adults. Biochem. J. 61, 629 .

Smithies, O. (1959) Zone electrophoresis in starch gels and its application to studies of serum proteins. Adv. Protein Chem. 14, 65.

Song, C. S., Rifkind, A. B., Gilette, P. N. \& Kappas, A. (1969) Hormones and the liver. The effect of oestrogens, progestins and pregnancy on hepatic function. Am. F. Obstet. Gynec. 105, 813.

Tyler, E. T. (1964) Eight years experience with oral contraception and an analysis of the use of low dosage norethisterone. Br. med. F. ii, 843.

Wetstone, H. J., Lamotta, R. V., Middlebrook, L., Tennant, R. \& White, B. V. (1958) Studies of cholinesterase activity. IV. Liver function in pregnancy: values of certain standard liver function tests in normal pregnancy. Am. 7. Obstet. Gynec. 76, 480.

WhITTAKER, M. (1970) Genetic aspects of succinyl choline sensitivity. Anesthesiology, 32, 143. 